\title{
Modulation of Insulinlike Growth Factor I Binding to Human Fibroblast Monolayer Cultures by Insulinlike Growth Factor Carrier Proteins Released to the Incubation Media
}

Monique A. De Vroede, Lucy Y.-H. Tseng, Panayotis G. Katsoyannis, S. Peter Nissley, and Matthew M. Rechler Molecular, Cellular, and Nutritional Endocrinology Branch, National Institute of Arthritis, Diabetes, and Digestive and Kidney Diseases, Developmental Endocrinology Branch, National Institute of Child Health and Human Development, and Metabolism Branch, National Cancer Institute, National Institutes of Health, Bethesda, Maryland 20892; Department of Biochemistry, Mount Sinai School of Medicine of the City University of New York, New York 10029

\section{Abstract}

The relative contributions of type I and type II insulinlike growth factor (IGF) receptors and IGF carrier proteins to the binding of IGF-I tracer to cultured human fibroblasts were determined in competitive binding experiments that used unlabeled insulin and synthetic insulin-IGF-I hybrid molecules containing the $A$ chain of insulin and the B domain of IGF-I. Whereas insulin binds only to type I IGF receptors, the B-IGF-I hybrids bind to type I receptors and IGF carrier proteins but not to type II receptors. In suspended human fibroblasts, IGF-I tracer binds predominantly to type I IGF receptors (inhibition by IGF-I $\gg$ insulin > B-IGF-I hybrid molecules). By contrast, in fibroblast monolayers, IGF-I binding was minimally inhibited by insulin or hybrid molecules, suggesting predominant binding to the type II IGF receptor. The type I receptor appears to be masked on fibroblast monolayers, and to require suspension or detergent solubilization of the cells to be demonstrated.

In the course of the monolayer binding experiments, we noted that low concentrations of unlabeled IGF-I $(5-10 \mathrm{ng} / \mathrm{ml})$ or BIGF-I hybrids $(100 \mathrm{ng} / \mathrm{ml})$ paradoxically increased IGF-I tracer binding up to twofold. We postulated that during the binding incubation $\left(5 \mathrm{~h}, 15^{\circ} \mathrm{C}\right)$, IGF-I tracer partitioned between binding sites on the cell surface and IGF carrier proteins released to the incubation media. Preferential occupancy of binding sites in the media by unlabeled ligand increased the tracer available to bind to the cells. In support of this hypothesis, carrier proteins were demonstrated in the media at the end of the binding incubation with fibroblast monolayers, and the concentration of unsaturated binding sites in the media correlated inversely with tracer binding to the cells. Thus carrier proteins released to the media during the binding incubation modulate the binding of IGF-I tracer to cell receptors, suggesting that the carrier proteins may play an important role in regulating cellular responsiveness to the IGFs.

\section{Introduction}

The insulinlike growth factors (IGFs), ${ }^{1}$ IGF-I and IGF-II, are plasma polypeptides chemically related to insulin and possessing

Dr. Katsoyannis is a member of the Department of Biochemistry, Mount Sinai School of Medicine of the City University of New York, New York 10029.

Address reprint requests to Dr. Rechler, National Institutes of Health, Building 10, Room 8D-14, Bethesda, MD 20892.

Received for publication 29 March 1985 and in revised form 15 October 1985.

1. Abbreviations used in this paper: HBB, Hepes binding buffer; IGF, insulinlike growth factor; MEM, minimal essential medium; MSA, multiplication-stimulating activity; PEG, polyethylene glycol.

The Journal of Clinical Investigation, Inc.

Volume 77, February 1986, 602-613 mitogenic activity (1). They exert their biological effects by interacting with specific IGF receptors on the surface of target cells (2-6). Two subtypes of IGF receptors have been identified. Type I IGF receptors are structurally homologous to insulin receptors, with disulfide-linked $\alpha$-subunits $\left(M_{\mathrm{r}} \sim 130,000\right)$ that bind the polypeptides and $\beta$-subunits $\left(M_{\mathrm{r}} \sim 90,000-100,000\right)$ that have intrinsic tyrosine kinase activity. Type I receptors typically have higher affinity for IGF-I than IGF-II, and also bind insulin with lower affinity. By contrast, type II receptors consist of a single $M_{\mathrm{r}} \sim 260,000$ protein that is not disulfide-linked to other membrane proteins and appears to lack tyrosine kinase activity. Type II IGF receptors bind IGF-II in preference to IGF-I, and do not bind insulin.

Because IGF-I and IGF-II bind to both type I and type II IGF receptors and also cross-react with insulin receptors, either of these three receptors might mediate their biological actions $(5,6)$. From dose-response curves and experiments using antireceptor antibodies to selectively block insulin receptors, it has been possible to identify IGF-stimulated functions that are mediated by IGF receptors rather than by insulin receptors $(5,7)$. It has been more difficult to resolve whether these effects are mediated by type I, type II, or both receptors. Some cells (e.g., chick embryo fibroblasts) only possess type I IGF receptors $(2,8)$, so it is quite likely that in these cells the type I receptor mediates IGF-stimulated DNA synthesis. Whether the type II receptor mediates the same or different functions as the type I receptor, or indeed whether it possesses any biological functions (9) remains to be demonstrated. One difficulty in answering this question has been the inability to unambiguously identify and quantitate type I and type II IGF receptors in a given cell.

We have been interested in studying the actions of IGFs and their receptors in cultured skin fibroblasts from normal donors and ultimately in patients with possible inherited resistance to the IGFs. IGF receptor-mediated stimulation of glucose uptake, amino acid transport, and DNA synthesis have been demonstrated in fibroblast cultures $(10,11)$. The nature of the IGF binding sites on cultured fibroblasts, however, remains unclear because the receptor profile varies under different assay conditions and in different laboratories. We previously reported that at steady state ${ }^{125}$ I-IGF-I binds to insulin-inhibitable type I IGF receptors on fibroblasts studied in suspension after treatment of the cells with trypsin-EDTA $(2,12-14)$. Moreover, ${ }^{125} \mathrm{I}-\mathrm{IGF}-\mathrm{I}$ bound to human fibroblast monolayers could be chemically cross-linked to the $\alpha$-subunit of the type I receptor; formation of this complex was inhibited in the presence of high concentrations of insulin (14). However, in these and similar crosslinking experiments, we were surprised to note that the total radioactivity bound to the fibroblast monolayer was inhibited by IGF-I but not by insulin (Kasuga, M., and M. M. Rechler, unpublished results). This specificity suggested that the predominant IGF-I binding in intact fibroblast monolayers was not to 
a type I receptor, but rather to type II IGF receptors and/or to IGF carrier proteins, because neither of these molecules bind insulin. Indeed, a labeled protein of appropriate molecular weight for an IGF-I-carrier protein complex had been observed on the cross-linking gel described by Rechler (14). Evidence from our laboratory and others suggested that both potential binding macromolecules were present in human fibroblast cultures (4, 14-16; Romanus, J. A., and M. M. Rechler, unpublished results). ${ }^{125}$ I-IGF-II was chemically cross-linked to an $M_{\mathrm{r}} 260,000$ type II receptor in a $100,000 \mathrm{~g}$ membrane fraction prepared from cultured fibroblasts, and containing plasma and microsomal membranes (4). IGF carrier proteins have been demonstrated indirectly $(14,15)$ and directly (16; Romanus, J. A., and M. M. Rechler, unpublished results) in media conditioned by human fibroblasts. Contrasting results were reported by Rosenfeld and Dollar (17), who observed that the binding of ${ }^{125}$ I-somatomedin C, presumably identical to IGF-I (18), to human fibroblast monolayers was inhibited $\sim 60 \%$ by insulin, and presumably represented predominantly binding to type I IGF receptors.

To determine the relative contributions of type I and type II receptors and IGF carrier proteins to the IGF-I binding to human fibroblasts observed under different experimental conditions, we have taken advantage of the recent observation that chemically synthesized hybrid molecules containing the A chain of insulin and the B domain of IGF-I bind to type I IGF receptors and IGF carrier proteins, but not to type II IGF receptors (19). Thus, the pattern of binding inhibition by insulin and the B-IGF-I hybrid molecules distinguishes the three binding macromolecules (Table I): type I IGF receptors bind insulin and $B_{\text {IGF-I }}$ hybrid molecules, IGF carrier proteins bind the hybrid molecules but not insulin, and type II IGF receptors do not bind either insulin or the hybrid molecules. We find that IGF-I binds predominantly to type I IGF receptors in suspended fibroblasts, and to type II receptors and possibly carrier proteins on fibroblast monolayers. In addition, IGF carrier proteins are released to the media during the binding incubation and appear to modulate IGF-I binding to the type I receptor.

\section{Methods}

Insulin-IGF hybrid molecules. Three insulin-IGF hybrid molecules were used in these studies: ( $a$ ) $\mathrm{A}_{\text {insulin }}-\mathrm{B}_{\mathrm{IGF-1}}$, a hybrid molecule containing the A chain of insulin and the B domain of IGF-I; (b) A27 insulin, in which the B chain of insulin is combined with a 27-residue A chain containing the 6-residue D domain of IGF-II as a $\mathrm{COOH}$-terminal extension of the 21-residue $A$ chain of insulin; and (c) A27 $7_{\text {insulin }}-B_{1 G F-1}$, in which the 27 residue A chain is combined with the B domain of IGF-I. Synthesis of

Table I. Competitive Inhibition of ${ }^{125}$ I-IGF-I Binding

\begin{tabular}{|c|c|c|c|}
\hline Peptide & $\begin{array}{l}\text { Type I } \\
\text { IGF receptor* }\end{array}$ & $\begin{array}{l}\text { Type II } \\
\text { IGF receptorł }\end{array}$ & $\begin{array}{l}\text { IGF } \\
\text { carrier } \\
\text { proteins§ }\end{array}$ \\
\hline IGF-I & + & + & + \\
\hline Insulin & + & - & - \\
\hline \multicolumn{4}{|l|}{$A_{\text {insulin }}-B_{\text {IGF-II }}$} \\
\hline$A 27_{\text {insulin }}-B_{1 G F-I}$ & + & - & + \\
\hline A27 insulin & + & - & - \\
\hline
\end{tabular}

* Relative potency: IGF-I $>$ insulin $>$ A27 $7_{\text {insulin }}>A_{\text {insulin }}-B_{\text {IGF-I }}$ (20). ¥ See DeVroede et al. (19).

$\S$ Relative potency: IGF-I $>A_{\text {insolin }}-B_{\text {IGF-I }}(19)$.
A27 insulin (21) and $A_{\text {insulin }}-B_{I G F-I}$ (22) have been described. The detailed synthesis of $A 27_{\text {insulin }}-B_{1 G F-I}$ will be reported elsewhere. In brief, insulin $A$ and $B$ chains were separated by oxidative sulfitolysis of bovine insulin and purified by column chromatography. The 27 -residue $A$ chain and the 30-residue B domain of IGF-I were synthesized from protected intermediate peptides using the fragment condensation method. The homogeneity of the synthetic chains was established by ion-exchange chromatography and thin-layer electrophoresis. Hybrids were constructed by combination of the sulfhydryl forms of the A chain of insulin or A27 insulin with the S-sulfonated forms of the B chain of insulin or synthetic IGF-I at pH 10.5 in the presence of thiols. The hybrid molecules were homogeneous by isoelectric focusing and/or reverse phase high-performance liquid chromatography $(21,22)$.

Other peptides. IGF-I (preparations 16SPII and I/4), IGF-II (preparation 9SEIV), and partially purifid IGF-I (preparation 1932; $36 \mathrm{mU} /$ mg insulinlike activity, $\sim 20 \%$ pure IGF-I by radioimmunoassay) were kind gifts of Prof. René Humbel (Zürich, Switzerland). Multiplicationstimulating activity (MSA) III-2 $\left(M_{\mathrm{r}} 7,100\right)$ was purified from serumfree media conditioned by BRL-3A cells as previously described (23). ${ }^{125} \mathrm{I}-\mathrm{IGF}-\mathrm{I}$ (sp act $40-250 \mathrm{Ci} / \mathrm{g}$ ) and ${ }^{125} \mathrm{I}-\mathrm{MSA}$ III-2 (sp act $150-468$ $\mathrm{Ci} / \mathrm{g}$ ) were prepared by a modified chloramine $\mathrm{T}$ procedure $(2,13)$. (The chloramine $\mathrm{T}$ concentration reported by Van Obberghen-Schilling et al. (13) should have been given as $333 \mathrm{ng} / 10 \mu \mathrm{l}$ ). Porcine insulin was purchased from Eli Lilly \& Co., Elanco Div. (Indianapolis, IN).

Cultivation of fibroblasts. Skin fibroblasts from three normal volunteers, male and female between 18 and 22 yr of age, were obtained from forearm punch biopsies. The cells were cultured in Eagle's minimal essential medium (MEM), supplemented with $10 \mathrm{mM}$ Hepes, nonessential amino acids, and $20 \%$ fetal calf serum. Fetal calf serum was obtained from one of two sources: Rehatuin FS lot u 50303 (Reheis Chemical Co., Armour Pharmaceutical Co., Phoenix, AZ) and HyClone lot 100382 (Sterile Systems Inc., Logan, UT). Stock cultures were grown as monolayers in 250-ml flasks (Falcon Labware, Becton Dickinson \& Co., Oxnard, $\mathrm{CA}$ ) at $37^{\circ} \mathrm{C}$ in $95 \%$ humidity and in a $95 \%$ air- $5 \% \mathrm{CO}_{2}$ atmosphere. The cells were routinely subcultured using $0.25 \%$ trypsin in Dulbecco's phosphate-buffered saline (PBS) without $\mathrm{Ca}^{++}$and $\mathrm{Mg}^{++}$, by a $1: 3$ or 1:4 split each week. Fibroblasts were used between passages 5 and 10 and were proven to be free of mycoplasma by culture assay (Microbiological Associates, Bethesda, MD).

Binding of IGF-I to human fibroblast monolayers cultivated in serum. Fibroblasts were grown in 250-ml Falcon flasks in Dulbecco's modified Eagle's medium containing $4.5 \mathrm{~g} /$ liter glucose or Eagle's MEM, supplemented with $20 \%$ fetal calf serum. Cells were plated at a density of 5,00010,000 cells $/ \mathrm{cm}^{2}$ in $60-\mathrm{mm}$ tissue culture dishes (Falcon), $35-\mathrm{mm}$ wells of six-well tissue culture plates (Falcon), or in 22-mm wells of 12-well tissue culture plates (Costar, Cambridge, MA) and grown to confluency. Cultures were fed at day 3, and used for assays 3-5 d later (final cell density 40,000-80,000 cells $/ \mathrm{cm}^{2}$ ).

${ }^{125}$ I-IGF-I binding was performed as described by Rosenfeld and Dollar (17). The culture medium was aspirated and the monolayer washed with PBS and pH 8.0 Hepes binding buffer (HBB) $(118 \mathrm{mM} \mathrm{NaCl} ; 5$ $\mathrm{mM} \mathrm{KCl} ; 1.2 \mathrm{mM} \mathrm{MgSO}_{4} ; 8.8 \mathrm{mM}$ dextrose; $100 \mathrm{mM}$ Hepes; albumin [Sigma Chemical Co., radioimmunoassay grade], $10 \mathrm{mg} / \mathrm{ml}$ ). Monolayers were incubated with ${ }^{125} \mathrm{I}$-IGF-I $(\sim 250 \mathrm{pg} / \mathrm{ml})$ and various concentrations of unlabeled peptides in $\mathrm{HBB}$ for $4-5 \mathrm{~h}$ at $15^{\circ} \mathrm{C}$ in a final volume of 2 $\mathrm{ml}$ per $60-\mathrm{mm}$ dish, $0.8 \mathrm{ml}$ per $35-\mathrm{mm}$ well, and $0.5 \mathrm{ml}$ per $22-\mathrm{mm}$ well. At the end of the incubation, the medium was aspirated and the monolayers were washed with ice cold Hanks' buffer or PBS, solubilized in $1.5 \mathrm{ml}$ of $1 \mathrm{~N} \mathrm{NaOH}$, and counted in a Beckman Instruments, Inc. (Palo Alto, CA) gamma counter with $75 \%$ efficiency.

Binding of IGF-I to fibroblast monolayers cultivated in serum-free media. Fibroblasts were plated at a density of $30,000-40,000 \mathrm{cells} / \mathrm{cm}^{2}$ in Dulbecco's modified Eagle's medium- $0.2 \%$ fetal calf serum in $60-\mathrm{mm}$ dishes, 35-mm wells of six-well tissue culture plates, or 22-mm wells of 12-well tissue culture plates, and were used within $3 \mathrm{~d}$ after plating. In some experiments, cells were washed after $48 \mathrm{~h}$ and the incubation medium was changed to Eagle's MEM containing $1 \mathrm{mg} / \mathrm{ml}$ albumin for the final $24 \mathrm{~h}$ before use. ${ }^{125} \mathrm{I}$-IGF-I binding was performed as described above. 
Binding of IGF-I to human fibroblasts in suspension. The binding assay was carried out as published previously (13). Briefly, fibroblasts were plated into $100-\mathrm{mm}$ plastic dishes in Eagle's MEM containing 20\% fetal calf serum, fed till confluency, and used 6-7 d after the last feeding. Fibroblasts were detached from the monolayer by washing with PBS without $\mathrm{Ca}^{++}$and $\mathrm{Mg}^{++}$, followed by incubation for 3-5 min at $37^{\circ} \mathrm{C}$ with $0.01 \%$ Trypsin- $0.5 \mathrm{mM}$ EDTA (Trypsin, 3,100 No-benzoyl-L-arginine ethyl ester U/mg, Worthington Biochemical Corp., Freehold, NJ). The reaction was terminated by adding an equal volume of $0.02 \%$ soybean trypsin inhibitor (Sigma Chemical Co., St. Louis, MO). The cells were collected, washed in Hepes binding buffer, sedimented, and resuspended in HBB. The incubation mixture consisted of ${ }^{125}$ I-labeled IGF-I, the indicated concentrations of unlabeled peptides and $1-2 \times 10^{6}$ cells in a total volume of $0.5 \mathrm{ml}$. After $3-4 \mathrm{~h}$ of incubation at $15^{\circ} \mathrm{C}, 0.2-\mathrm{ml}$ aliquots were pipetted in duplicate onto ice-cold buffer $(0.2 \mathrm{ml}$ of HBB). The tubes were centrifuged in a Beckman microfuge for $1 \mathrm{~min}$ and the supernate was aspirated. The tips containing the cell pellets were excised and the associated radioactivity was quantitated in a gamma counter.

Precipitation of binding assay supernate with polyethylene glycol. In some experiments, at the end of the binding incubation, the supernatant was recovered and incubated with polyethylene glycol (PEG) to identify ${ }^{125}$ I-IGF-I bound to macromolecular components (24). To $0.5 \mathrm{ml}$ of medium was added $0.5 \mathrm{ml}$ of human $\gamma$-globulin $(2 \mathrm{mg} / \mathrm{ml}$; Pentex, Miles Laboratories, Inc., Elkhart, IN) and $1 \mathrm{ml}$ of $25 \%$ (wt/vol) PEG $(6,000$ 8,000 ), and the mixture was incubated on ice for $15 \mathrm{~min}$. After centrifugation at $3,000 \mathrm{rpm}$ for $20 \mathrm{~min}$ at $4^{\circ} \mathrm{C}$ in a Beckman TJ6 centrifuge, the supernate was aspirated and the precipitated radioactivity quantitated in a Beckman gamma counter. Results were corrected for the "blank," i.e., the radioactivity precipitated by PEG- $\gamma$-globulin from the same amount of radioactive ligand in binding buffer that had not been incubated with cells. Typically, this represented $10-15 \%$ of the input radioactivity.

${ }^{125}$ I-IGF-I-carrier protein complexes are not completely precipitated by $12.5 \%$ PEG. In a control experiment (not shown), ${ }^{125}$ I-IGF-I was incubated with human fibroblast-conditioned media, and the per cent of input radioactivity specifically complexed to carrier protein determined by different methods: gel filtration (Sephadex G-50, neutral pH), 33.4\%; charcoal separation $(19,25), 20.3 \%$; precipitation with $20 \%$ PEG, $24.5 \%$; and precipitation with $12.5 \%$ PEG, $8.7 \%$. Thus, under the conditions used in our experiments, a maximum of $25 \%$ of the total radioligandcarrier protein complexes are precipitated.

Competitive binding protein assay. IGF-binding macromolecules in media conditioned by $5 \mathrm{~h}$ of incubation with fibroblast monolayers at $15^{\circ} \mathrm{C}$ in binding assay buffer also were examined in a direct binding assay using ${ }^{125}$ I-labeled MSA (equivalent to rat IGF-II). Aliquots of media were incubated with ${ }^{125}$ I-MSA III-2 and the indicated concentrations of unlabeled peptides in $0.4 \mathrm{ml}$ of PBS containing $2 \mathrm{mg} / \mathrm{ml}$ fatty acid-free bovine serum albumin (Sigma Chemical Co.) overnight at $4^{\circ} \mathrm{C}$. Tracer MSA not complexed to binding protein was removed by adsorption with activated charcoal as previously described $(19,25)$. Complexes of ${ }^{125} \mathrm{I}$ MSA III-2 with carrier protein remained in the charcoal supernate and were quantitated. Radioactivity in the charcoal supernate in the absence of added carrier protein has been subtracted from each point.

IGF-I binding to detergent-solubilized monolayer cultures. Solubilization of fibroblasts with Triton X-100 was performed according to Cuatrecasas (26). Each 22-mm well was washed with PBS and HBB, and solubilized by addition of $50 \mu \mathrm{l}$ of $1 \%$ (vol/vol) Triton X-100 (Research Products International Corp., Elk Grove Village, IL) for $30 \mathrm{~min}$ on a rocking platform at $4^{\circ} \mathrm{C}$. The mixture containing the dissolved cells was diluted in $500 \mu \mathrm{l}$ of pH $8.0 \mathrm{HBB}$ containing the radioactive ligand and the indicated concentrations of unlabeled peptides. The reaction was stopped after $5 \mathrm{~h}$ at $15^{\circ} \mathrm{C}$ (or $18 \mathrm{~h}$ at $4^{\circ} \mathrm{C}$ ) by adding $0.5 \mathrm{ml}$ of $\gamma$-globulin and $1 \mathrm{ml}$ of $25 \%$ PEG; the mixture was kept on ice for $15 \mathrm{~min}$, centrifuged (20 $\mathrm{min}, 3,000 \mathrm{rpm}$ ) and radioactivity in the precipitate quantitated. All values were corrected for the amount of radioactivity that is precipitated by $\gamma$-globulin and PEG in the absence of solubilized cells.

In some experiments (as specified), a solubilization buffer (modified from Reference 27) containing $1 \%(w t / v o l)$ Triton X-100 in $150 \mathrm{mM}$ $\mathrm{NaCl}, 5 \mathrm{mM}$ EDTA, $1 \%$ (wt/vol) sodium deoxycholate (TES), and 0.1
M Tris- $\mathrm{HCl}$, $\mathrm{pH} 7.4$, with or without $2 \% \mathrm{~N}$-octylglucoside (CalbiochemBehring Corp., San Diego, CA) was used in the same manner.

\section{Results}

Inhibition of IGF-I tracer binding to suspended fibroblasts and to fibroblast monolayers by IGF-I and insulin. Fig. $1 C$ demonstrates that ${ }^{125} \mathrm{I}-\mathrm{IGF}-\mathrm{I}$ binds to a typical type I IGF receptor on fibroblasts grown to confluence in serum-containing medium and suspended by mild trypsinization. Tracer binding is inhibited $50 \%$ by $5.8 \pm 2.9 \mathrm{ng} / \mathrm{ml}(n=8)$ of IGF-I. Insulin gave dose-dependent inhibition of binding at higher concentrations: $\sim 50 \%$ inhibition at $\sim 550 \mathrm{ng} / \mathrm{ml}$ and $\sim 90 \%$ inhibition at $10 \mu \mathrm{g} / \mathrm{ml}$. A specificity profile consistent with binding to a type I receptor also was observed in fibroblasts grown in serum-free medium and studied after suspension (data not shown).

Markedly different results were obtained when binding was performed in situ on fibroblasts cultivated in serum-containing medium (Fig. $1 A$ ). Binding of tracer IGF-I in the presence of different concentrations of unlabeled IGF-I gave a biphasic curve: at lower concentrations of IGF-I ( $\leq 10 \mathrm{ng} / \mathrm{ml})$, binding increased to a variable maximum (105-250\% of control), whereas dosedependent inhibition was observed at IGF-I concentrations from $10 \mathrm{ng} / \mathrm{ml}$ to $1 \mu \mathrm{g} / \mathrm{ml}$. Insulin gave a partial inhibition at high concentration $(\sim 30 \%$ at $10 \mu \mathrm{g} / \mathrm{ml})$, and did not increase IGFI tracer binding at lower concentrations $(0.1$ and $1 \mu \mathrm{g} / \mathrm{ml})$. The increased binding at low concentrations of IGF-I was observed with cells grown under different cultivation conditions-in fetal calf serum obtained from two sources, on culture plates of different size $(22,35$, or $60 \mathrm{~mm})$ obtained from different sources, and with different feeding schedules (zero, one, or two feedings). The two points with highest binding were obtained with fibroblasts plated in $60-\mathrm{mm}$ dishes, and fed twice with media containing serum from Reheis Chemical Co. The relative contributions of these culture conditions to the increased binding have not been determined.

Binding of IGF-I to cell monolayers also was examined in cells plated in serum-poor medium $(0.2 \%$ fetal calf serum) and changed to serum-free medium prior to assay (Fig. $1 \mathrm{~B}$ ). Under these conditions, unlabeled IGF-I at low concentration increased tracer IGF-I binding to a modest extent ( $\sim 115 \%$ of control) in only 2 of 12 experiments, and did not increase binding in the other 10 experiments. Insulin again gave negligible inhibition of binding $(\sim 10 \%)$ at $10 \mu \mathrm{g} / \mathrm{ml}$.

The different effects of insulin on IGF-I binding to suspended cells and in situ suggested that, although tracer IGF-I bound predominantly to a type I IGF receptor in suspended cells, binding to this receptor constituted a minor portion of total binding to cell monolayers irrespective of whether the cells had been grown in serum-containing or serum-free media. Moreover, the surprising increase in tracer IGF-I binding to fibroblast monolayers, especially in cells grown in the presence of serum, was not observed when binding was performed with suspended fibroblasts.

Inhibition of tracer binding to suspended fibroblasts and to fibroblast monolayers by insulin-IGF-I hybrid molecules. In an attempt to clarify the nature of the binding sites for IGF-I in cell monolayers, binding inhibition studies were performed using insulin-IGF hybrid molecules (Fig. 2). The three hybrid molecules gave extensive dose-dependent inhibition of tracer IGF-I binding to suspended fibroblasts (Fig. $2 C$ ). IGF-I, insulin, A27 insulin, $A_{\text {insulin }}-B_{\text {IGF-I }}$ and $A 27_{\text {insulin }}-B_{\text {IGF-I }}$ inhibited binding in the stated order of potency. Similar results were observed for 


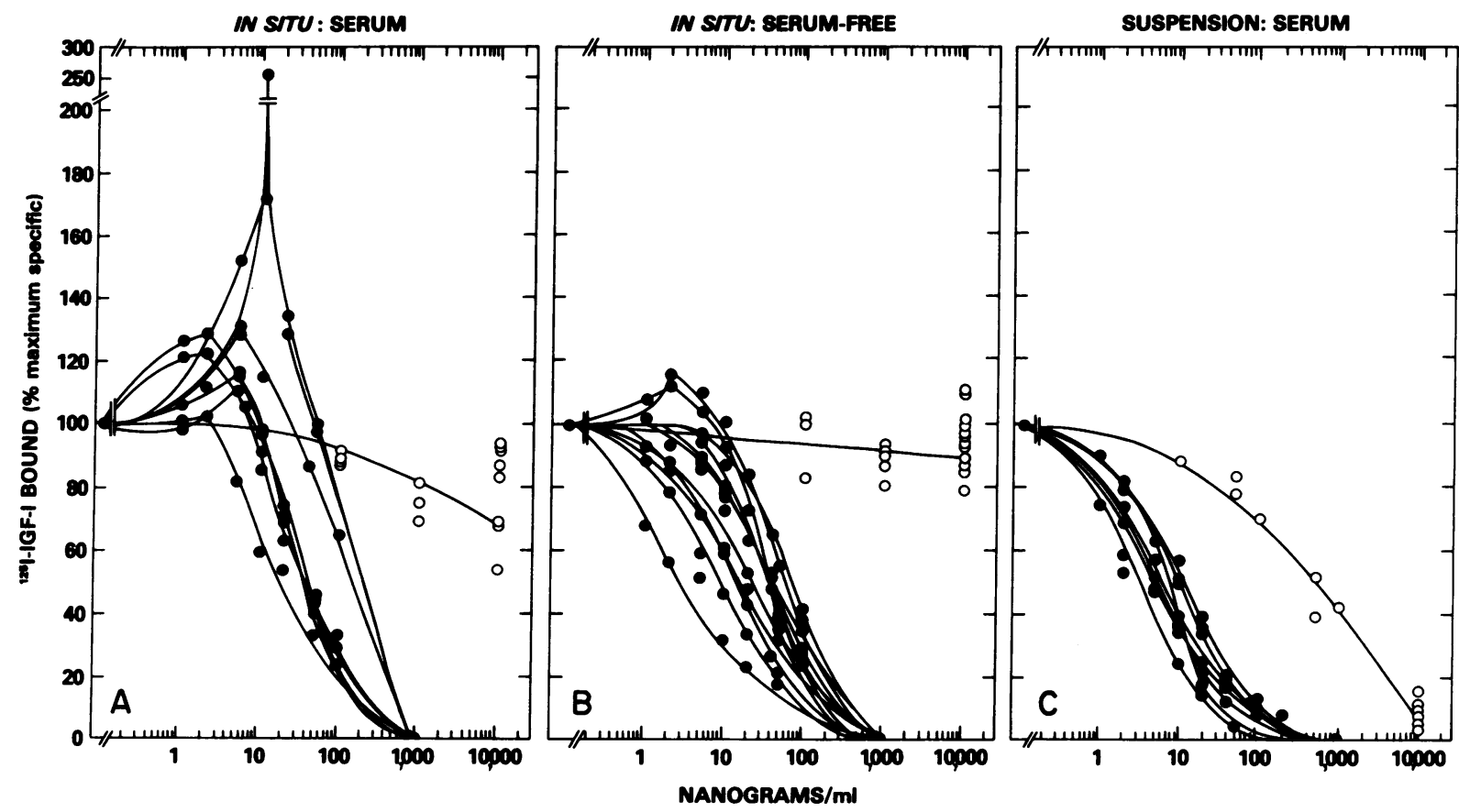

Figure 1. Inhibition of ${ }^{125}$ I-IGF-I binding to human fibroblast monolayers cultivated in serum-containing $(A)$ or serum-free $(B)$ media, and to human fibroblasts cultivated in serum-containing media and studied in suspension $(C)$ by different concentrations of unlabeled IGF-I $(\bullet)$ and insulin (O). In this and subsequent experiments, the points plotted as $1,000 \mathrm{ng} / \mathrm{ml} \mathrm{IGF-I} \mathrm{represent} 5,000 \mathrm{ng} / \mathrm{ml}$ of partially purified IGF (36 mU/mg). ( $A$ ) Human fibroblasts were plated in Eagle's MEM-20\% fetal calf serum and fed till confluence. Binding was per- formed as described in Methods. Results are expressed as percent maximum specific binding. Results from eight experiments are plotted. $(B)$ Human fibroblasts were plated in Eagle's MEM-0.2\% fetal calf serum for $48 \mathrm{~h}$ and then incubated with Eagle's MEM-1 mg/ml albu$\min$ for $24 \mathrm{~h}$. The results of 12 experiments are shown. $(C)$ Human fibroblasts were grown to confluence in Eagle's MEM-20\% fetal calf serum and suspended by mild trypsinization as described in Methods. The results of eight experiments are shown.
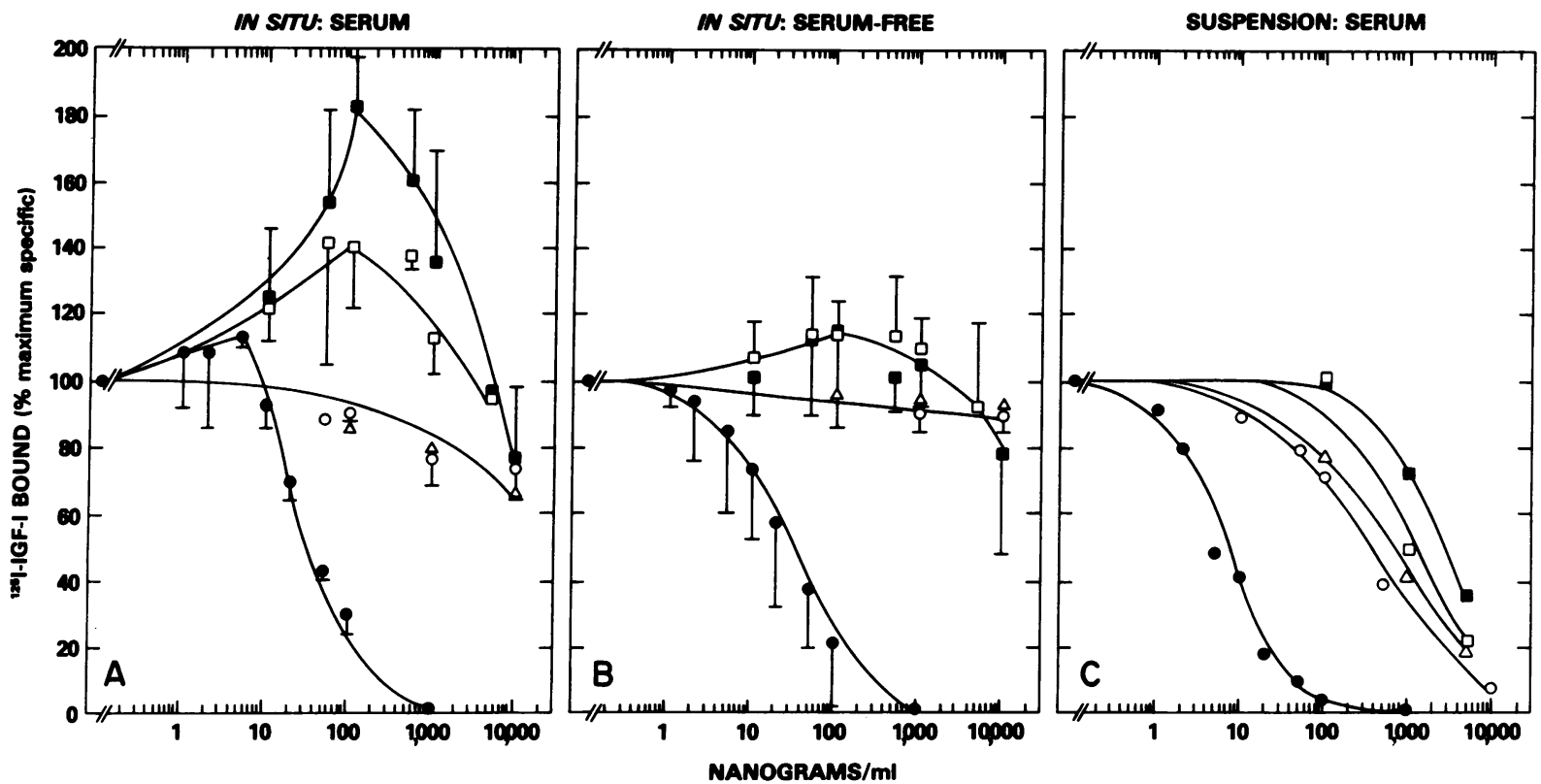

Figure 2. Inhibition of ${ }^{125}$ I-IGF-I binding to human fibroblast monolayers cultivated in serum-containing $(A)$ or serum-free $(B)$ media, and to human fibroblasts cultivated in serum and studied in suspension $(C)$ by the indicated concentrations of unlabeled IGF-I (•), insulin (O), A27 insulin $(\Delta), A_{\text {insulin }}-B_{\text {IGF-I }}(\square)$, and A27 insulin- $B_{\text {IGF-I }}(\bullet)$. Incubations were performed as described in Methods. $(A)$ Binding in situ to fibroblasts grown to confluence in Eagle's MEM-20\% fetal calf serum (Hyclone). Results are expressed as percent of maximum specific binding and represent the mean \pm 1 SD for three experiments in which the range of maximum specific binding was 3.2-4.9\% (0.6-1.2 $\times 10^{6}$ cells per point). ( $B$ ) Binding to fibroblasts plated in Eagle's MEM- $0.2 \%$ fetal calf serum for $48 \mathrm{~h}$ and then incubated with Eagle's MEM-1 mg/ml albumin for $24 \mathrm{~h}$. Results are expressed as percent maximum specific binding and represent the mean \pm 1 SD of three experiments, performed in parallel with the experiments shown in the left panel. The maximum specific binding was between 9.1 and $12.6 \%(230,000$ cells per point). $(C)$ Binding to suspended fibroblasts obtained by gentle trypsinization of monolayers grown to confluence in Eagle's MEM$20 \%$ fetal calf serum. A representative experiment is shown. Results are expressed as percent maximum specific binding ( $8.83 \%$ for 1.25 $\times 10^{6}$ cells). 


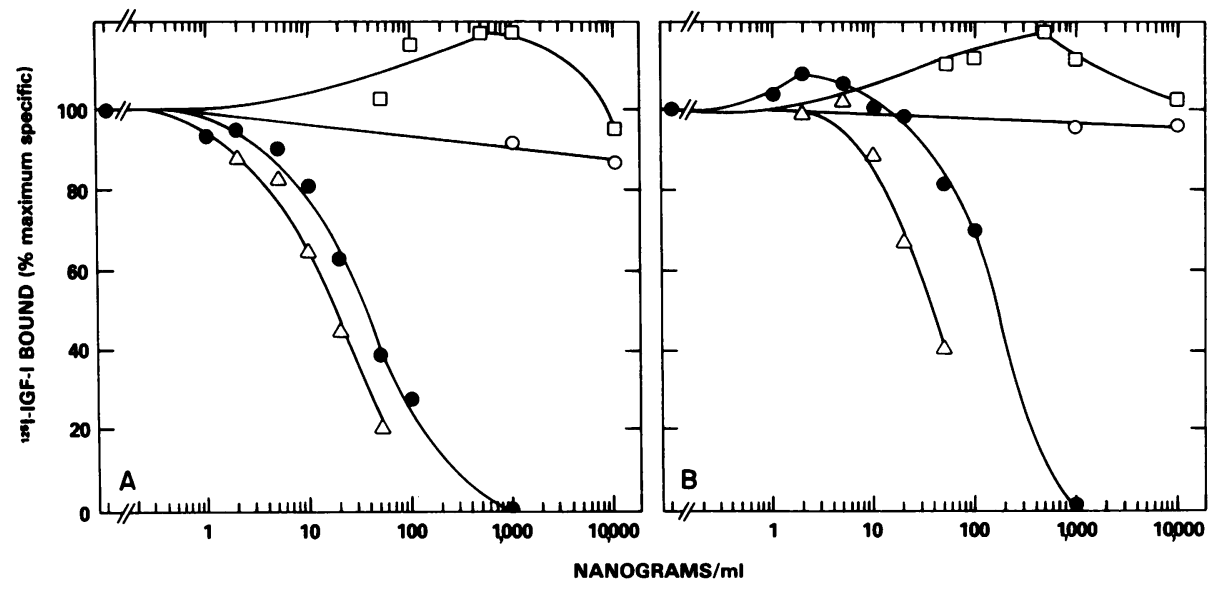

Figure 3. Inhibition of binding of ${ }^{125}$ I-IGF-I $(A)$ or ${ }^{125}$ I-MSAIII-2 $(B)$ to human fibroblast monolayers cultivated in serum-free conditions by different concentrations of unlabeled IGF-II ( $\Delta)$, IGF-I (•), insulin (O), or $A_{\text {insulin }}-B_{\text {IGF-I }}$ (口). Percent maximum specific binding (9.8\% and $11.9 \%$ of input reactivity, respectively) is plotted against concentration of unlabeled peptide.

inhibition of ${ }^{125} \mathrm{I}-\mathrm{IGF}-\mathrm{I}$ binding to the type I IGF receptor of chick embryo fibroblasts by these molecules (20).

Dramatically different results were observed when IGF-I tracer binding to fibroblast monolayers was examined in the presence of the hybrid molecules containing $\mathrm{B}_{\text {IGF-I }}$. With cells cultivated in serum-containing medium (Fig. $2 A$ ), ${ }^{125} \mathrm{I}-\mathrm{IGF}-\mathrm{I}$ binding in the presence of the hybrid molecules gave a more pronounced biphasic curve than that observed with unlabeled IGF-I. Whereas unlabeled IGF-I modestly increased IGF-I tracer binding at concentrations of $1-5 \mathrm{ng} / \mathrm{ml}$ (reaching a maximum of $112 \%$ of control), the $B_{1 G F-I}$ hybrid molecules at concentrations of $10-100 \mathrm{ng} / \mathrm{ml}$ increased IGF-I binding to a greater extent, reaching maxima of $140 \%$ and $180 \%$ of control. At concentrations from $100 \mathrm{ng} / \mathrm{ml}$ to $10 \mu \mathrm{g} / \mathrm{ml}$, the hybrid molecules gave dose-dependent but partial inhibition of binding (i.e., $<30 \%$ inhibition of the binding observed with IGF-I tracer alone).

The increased binding of IGF-I tracer in the presence of optimal concentrations of B-IGF-I hybrid does not represent protection of the tracer against proteolysis. IGF-I tracer recovered from the supernate after $5 \mathrm{~h}$ of incubation with fibroblast monolayers in the absence or presence of unlabeled peptide was $>95 \%$ precipitable by $10 \%$ trichloroacetic acid, indicating that the tracer had not been degraded to smaller fragments during the binding incubation.

Qualitatively similar but quantitatively smaller increases were observed in tracer IGF-I binding to monolayers incubated in

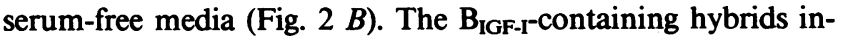
creased tracer IGF-I binding to a maximum of $115 \%$ of control binding at $\sim 100 \mathrm{ng} / \mathrm{ml}$, and gave $<20 \%$ inhibition of binding at $10 \mu \mathrm{g} / \mathrm{ml}$.

Fig. 3 demonstrates that the specificity of inhibition of tracer binding by different unlabeled peptides to human fibroblast monolayers cultivated in serum-free media was the same whether MSA III-2 (rat IGF-II) or IGF-I was used as radioligand. With either radioligand, unlabeled IGF-I and IGF-II gave dose-depenent inhibition, with IGF-II two to four times more potent than IGF-I. Insulin gave only 5-15\% inhibition of binding at high concentrations $(10 \mu \mathrm{g} / \mathrm{ml})$. The $B_{\text {IGF-I }}$ hybrid molecules gave a biphasic curve, with tracer binding increasing at lower concentrations of hybrid $(500-1,000 \mathrm{ng} / \mathrm{ml})$ to $\sim 120 \%$ of control, followed by a decrease to $95-100 \%$ of control at $10 \mu \mathrm{g} / \mathrm{ml}$. These results indicate that ${ }^{125} \mathrm{I}$-IGF-I and ${ }^{125} \mathrm{I}-\mathrm{MSA}$ III-2 bind to the same or similar sites on fibroblast monolayers cultivated in serum-free medium. Because this binding is not inhibited by the B-IGF-I hybrid molecules or insulin at high concentrations, we provisionally identify the major binding site as the type II IGF receptor. ${ }^{2}$

Cells cultivated in serum-containing media release IGF carrier proteins to the incubation media during IGF-I binding to monolayer cultures. We next examined the basis for the pronounced effects of IGF-I and $\mathrm{B}_{\mathrm{IGF}-\mathrm{I}}$-containing hybrid molecules on increasing tracer IGF-I binding to monolayers of fibroblasts cultured in serum-containing media. Because fibroblasts synthesize and secrete IGF carrier proteins into serum-free culture media during prolonged incubation (16; Romanus, J. A., and M. M. Rechler, unpublished results), we asked whether binding macromolecules also were released to the incubation media during the briefer binding incubation. Cell monolayers were incubated with ${ }^{125} \mathrm{I}-\mathrm{IGF}-\mathrm{I}$ for $5 \mathrm{~h}$ at $15^{\circ} \mathrm{C}$ under standard binding assay conditions, and binding to the cell monolayers was determined. In addition, at the end of the incubation, the media were recovered and incubated with $12.5 \%$ PEG in the presence of $\gamma$ globulin carrier to precipitate higher molecular weight complexes. PEG precipitated $11.5 \%$ of the input radioactivity from the incubation media, contrasted with only $3.6 \%$ that was bound to the cells (Fig. $4 \mathrm{~A}$ ).

In a parallel set of cultures, fibroblast monolayers were preincubated in binding buffer for $5 \mathrm{~h}$ at $15^{\circ} \mathrm{C}$, after which the media were aspirated and the cells incubated with ${ }^{125}$ I-IGF-I in fresh binding buffer $\left(5 \mathrm{~h}, 15^{\circ} \mathrm{C}\right)$; binding to cells and to PEGprecipitable proteins in the media was determined (Fig. $4 A$, + preincubation). After preincubation in buffer, ${ }^{125}$ I-IGF-I binding to fibroblasts increased by $180 \%$, whereas tracer binding to media proteins decreased by approximately threefold.

These results suggested that macromolecules (presumably proteins) capable of binding ${ }^{125}$ I-IGF-I were released from fibroblast monolayers during a 5-h preincubation in buffer. The specificity of this binding was determined by incubating aliquots of the recovered media with ${ }^{125} \mathrm{I}-\mathrm{MSA}$-III-2 and different concentrations of unlabeled IGF-I or A27 insulin-B $\mathrm{B}_{\text {IGF-I }}$; radioligand bound to macromolecules remains in the supernate after adsorption of free radioligand with activated charcoal and was quantitated. As seen in Fig. $4 \mathrm{~B}$, the hybrid molecule effectively

2. Because type II IGF receptors have not been directly identified on the surface of human fibroblast monolayers (e.g., by affinity cross-linking or immunoprecipitation), this assignment must only be considered provisional. We cannot exclude the possibility that this binding represents an atypical receptor or a cell-associated carrier protein that does not recognize the B-IGF-I hybrid molecules. 


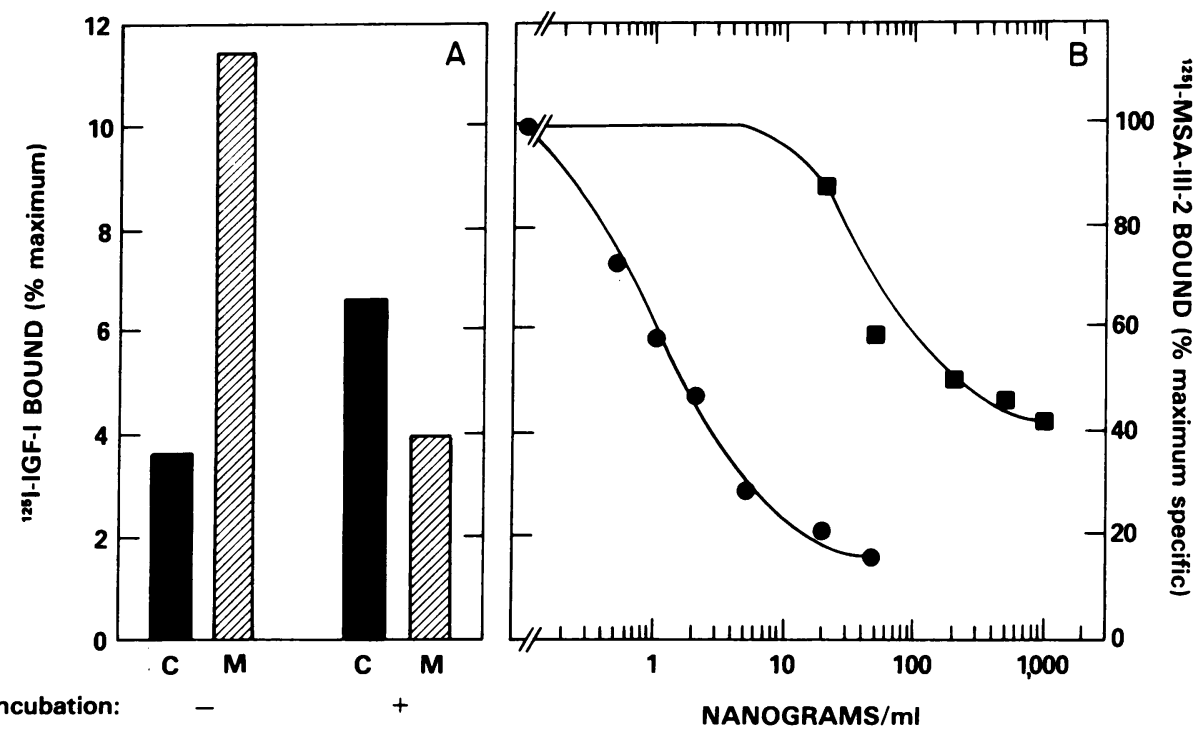

Figure 4. (A) Effect of preincubation of fibroblast monolayers on ${ }^{125}$ I-IGF-I binding to cells (C) and media proteins (M). Fibroblast monolayers were grown to confluence in Eagle's MEM-20\% fetal calf serum. To one set of cultures $(-),{ }^{125}$ I-IGF-I binding to cell monolayers was determined after incubation in $\mathrm{HBB}$ for $5 \mathrm{~h}$ at $15^{\circ} \mathrm{C}$ as described in Methods. At the end of the incubation, the assay media were precipitated with PEG- $\gamma$-globulin; correction was made for the radioactivity precipitated from tracer and buffer that had not been incubated with cells. Results are expressed as percent total input radioactivity. The solid bars $(\boldsymbol{\square})$ represent the cell-associated ${ }^{125}$ I-IGF-I binding, whereas the hatched bars $(\mathbb{\theta})$ represent the ${ }^{125}$ I-IGF-I binding precipitated by PEG- $\gamma$-globulin in the assay media at the end of the incubation. The second set of cultures $(+)$ was preincubated in HBB for $5 \mathrm{~h}$ at $15^{\circ} \mathrm{C}$, after which the buffer was aspirated, and fresh incubation buffer containing ${ }^{125}$ I-IGF-I was added. Tracer radioactivity bound to the cell monolayers and to media proteins was determined as described above. $(B)$ Specificity of ${ }^{125}$ I-MSA-III-2 binding to media macromolecules released after preincubation with fibroblast monolayers. Aliquots of media harvested from the second set of cultures $(+)$ described

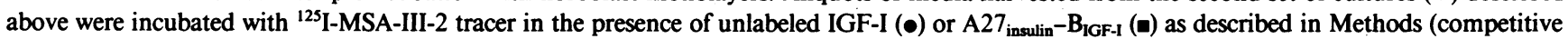
binding protein assay). Results are expressed as percent maximum specific binding (100\% corresponds to $13.43 \%$ of input radioactivity).

competed for ${ }^{125}$ I-MSA III-2 binding at concentrations 100 times greater than IGF-I. Insulin did not inhibit binding (not shown). These results suggest that the IGF-binding macromolecules released from fibroblast monolayers after brief $(5 \mathrm{~h})$ incubation in buffer have a binding specificity appropriate for IGF carrier proteins.

The biphasic binding curves for ${ }^{125}$ I-IGF-I binding to fibroblast monolayers reflect saturation of the alternative binding sites for radioligand in the culture media. The release of IGF carrier proteins by fibroblast monolayers during the binding incubation that were capable of interacting with IGF-I or $B_{\text {IGF-I }}$ hybrid molecules provided a possible explanation for the observed biphasic binding curves. Carrier proteins in the incubation media bind IGF-I tracer, decreasing the radioligand available for binding to cell receptor sites. Unlabeled peptides (e.g., B BGF-I hybrid molecules) having greater affinity for carrier proteins than for cell receptors (especially the predominant type II receptor) should preferentially bind to carrier proteins in the incubation media, thereby presenting a higher concentration of IGF-I tracer to the cells.

To test this hypothesis, fibroblast monolayers were incubated with ${ }^{125}$ I-IGF-I tracer in the presence of different concentrations of IGF-I, insulin, or A27 insulin-B $\mathrm{B}_{\mathrm{IGF}-\mathrm{I}}$. Radioligand bound to the cells and to the media binding proteins at the end of the incubation was determined (Fig. 5). IGF-I tracer binding to cells increased in the presence of 1-2 ng/ml of IGF-I or $20-100 \mathrm{ng} /$ $\mathrm{ml}$ of hybrid, and was inhibited completely or partially by higher concentrations of IGF-I or hybrid molecule, respectively. Unlabeled insulin gave a small $(\sim 20 \%)$ decrease in cell-associated binding, and did not significantly inhibit IGF-I tracer binding to carrier proteins in the media.

These results are consistent with the interpretation that tracer IGF-I partitions between cell-associated binding sites and binding sites in the media. Unlabeled IGF-I binds to both carrier proteins in the media and IGF receptors on the cell surface. At low concentrations, it has some preference for binding to the carrier protein rather than type II receptors on the cell, accounting for the modest increase in cell-associated binding to fibroblast monolayers at these concentrations. At higher concentrations of unlabeled IGF-I, the binding sites in the media become saturated, and further increases in unlabeled IGF-I concentration competitively decrease radioligand binding to cell-associated receptors.

The greater enhancement of IGF-I tracer binding to fibroblast monolayers by $B_{\text {IGF-I }}$ hybrid molecules reflects their selective interaction with IGF carrier proteins. At concentrations $\leq 100$ $\mathrm{ng} / \mathrm{ml}$, the hybrid molecule increased IGF-I binding in dosedependent fashion to a maximum of $190 \%$ of control. Over the same concentration range, a reciprocal decrease in tracer IGFI binding to IGF carrier proteins in the media was observed (Fig. $5 \mathrm{~B})$. At higher concentrations of the hybrid molecule (200$10,000 \mathrm{ng} / \mathrm{ml}$ ), IGF-I binding sites on carrier proteins in the media became saturated, and cell-associated binding decreased from $190 \%$ to $95 \%$ of the binding observed with IGF-I tracer alone. The fraction of IGF-I tracer binding that is inhibited by the hybrid molecule might represent type I IGF receptors or cell-associated carrier protein. The residual binding of ${ }^{125}$ I-IGFI to fibroblast monolayers in the presence of $10 \mu \mathrm{g} / \mathrm{ml}$ of $B_{\text {IGF-I }}$ hybrid presumably represents binding to the type II IGF receptor, although the possibility that this represents binding to a carrier protein with very low affinity for the hybrid molecule cannot be excluded. ${ }^{2}$

Fibroblast monolayers cultivated in serum-free media release less IGF carrier protein to the incubation media. The preceding results suggested that the upward limb of the biphasic competition curves observed for tracer IGF-I binding to fibroblast monolayers grown in the presence of serum resulted in large part from the presence of IGF carrier proteins in the incubation media. Because a much smaller increase in tracer IGF-I binding in the presence of low concentrations of IGF-I or $B_{\text {IGF-I }}$ hybrid molecules was observed when fibroblasts were maintained in serum-free media, it was anticipated that lower concentrations 

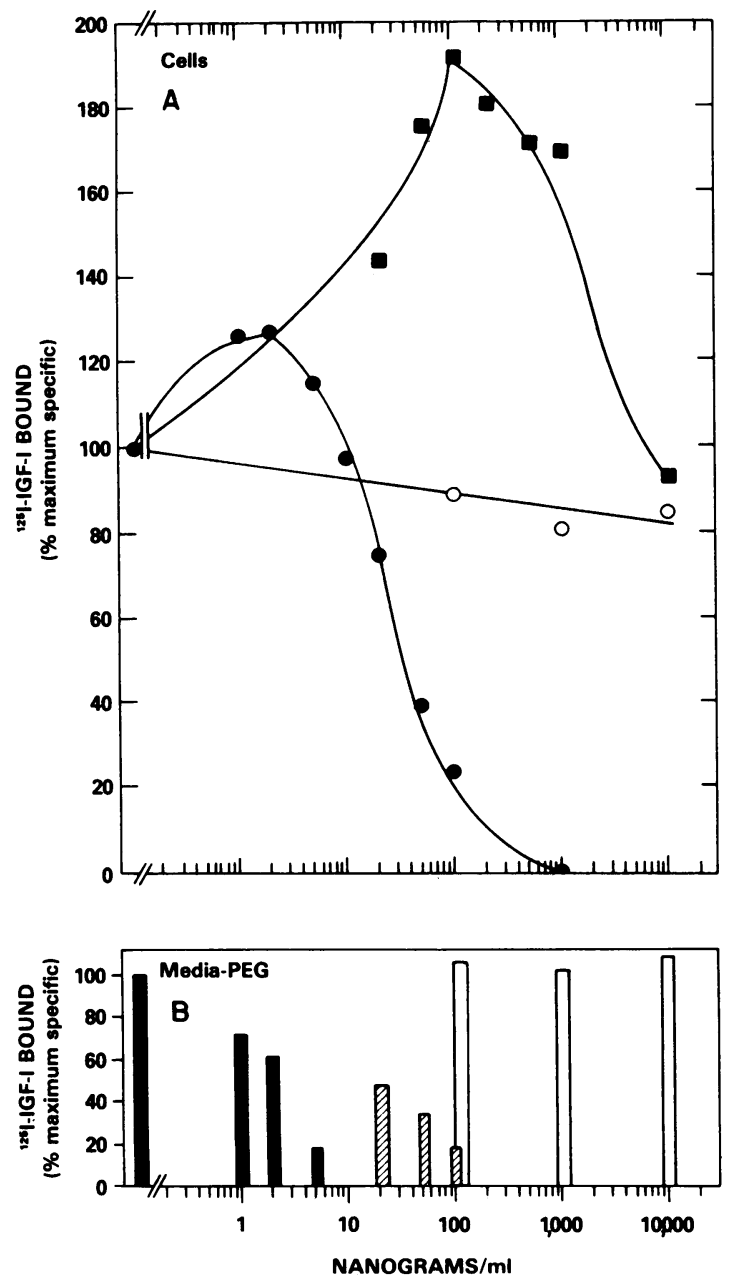

Figure 5. Inhibition of ${ }^{125}$ I-IGF-I binding to fibroblast monolayers $(A)$ and media proteins $(B)$ by unlabeled IGF-I $(\bullet, \sigma), A 27_{\text {insulin }}-B_{\text {IGF-I }}(\square$, $\square)$, or insulin $(O, \square)$. Fibroblasts were grown to confluence in Eagle's MEM-20\% fetal calf serum. $(A){ }^{125}$ I-IGF-I binding to fibroblast monolayers was determined in the presence of the indicated peptides. Percent maximum specific binding ( $3.66 \%$ of input radioactivity) is plotted. $(B)$ At the end of the binding incubation, the medium was aspirated, and precipitated with PEG- $\gamma$-globulin as described in Methods. Radioactivity specifically precipitated (i.e., after correction for the blank) is plotted as percent of maximum $(9.89 \%$ of the radioactivity initially incubated with the cell monolayer). No ${ }^{125}$ I-IGF-I was specifically precipitated in the presence of $\geq 10 \mathrm{ng} / \mathrm{ml}$ of unlabeled IGF-I or $\geq 200 \mathrm{ng} / \mathrm{ml}$ of $A 27_{\text {insulin }}-B_{\text {IGF-I }}$ (points not plotted).

of carrier protein would be present in incubation media from cells cultivated under these conditions. This prediction is confirmed in the three paired experiments depicted in Fig. 6. For cells cultivated in serum-free media, cell-associated radioactivity was $\sim 3.5$ times greater than radioactivity bound to IGF carrier proteins in the media: i.e., $8.29 \pm 1 \%$ vs. $2.37 \pm 1.3 \%$. By contrast, for cells grown in the presence of serum, $\sim 2.25$ times more IGF-I radioactivity was bound to incubation media containing IGF carrier proteins than to fibroblast monolayers (i.e., $7.91 \pm 1.18 \%$ vs. $3.52 \pm 1.5 \%$, respectively). Thus, in fibroblasts cultivated in serum-free media, IGF-I tracer binding to media proteins is reduced but not abolished.

Suspended fibroblasts do not release IGF carrier proteins to the incubation media. In competitive binding experiments in suspended fibroblasts, curves obtained with unlabeled IGF-I or B-IGF-I hybrid molecules are monophasic; that is, no increase

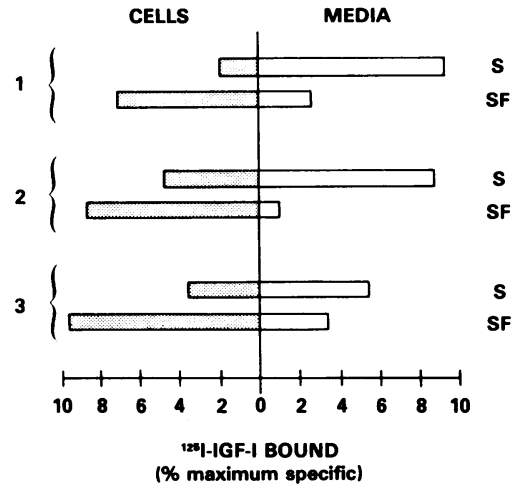

Figure 6. Distribution of ${ }^{125} \mathrm{I}-\mathrm{IGF}-\mathrm{I}$ bound to cell monolayers and media proteins for fibroblasts cultivated in serum-containing (S) or serum-free (SF) media. Fibroblasts (S) were plated in Eagle's MEM$20 \%$ fetal calf serum $(50,000$ cells $/ 22-\mathrm{mm}$ well) and grown to confluence $(350,000$ cells, $72 \mu \mathrm{g}$ of protein [Bio-Rad assay], per well). Fibroblasts (SF) were plated in Eagle's MEM-0.2\% fetal calf serum $(150,000$ cells/22-mm well) for $48 \mathrm{~h}$, followed by $24 \mathrm{~h}$ of incubation in Eagle's MEM-1 mg/ml bovine serum albumin (final concentration 150,000 cells, $40 \mu \mathrm{g}$ of protein, per well). In experiment 2 , cells were plated in 60-mm dishes, resulting in somewhat higher final protein concentrations (300 and $270 \mu \mathrm{g} /$ well for serum and serum-free conditions, respectively). ${ }^{125}$ I-IGF-I binding to cell monolayers (․ㅏ) and to media proteins ( $\square$ ) were determined as described in Fig. 5. The percent maximum specific ${ }^{125}$ I-IGF-I bound is shown for three paired experiments.

in IGF-I tracer binding is observed at lower concentrations of unlabeled peptide. If the increased binding observed to fibroblast monolayers reflects the presence of IGF carrier proteins in the media as proposed, one would not expect carrier proteins to be present in media conditioned by suspended fibroblasts. This is demonstrated in Fig. 7. Duplicate fibroblast monolayer cultures were grown to confluence in serum-containing media. Binding was performed directly to the monolayer or after suspension of the cells. Media recovered after incubation with cell monolayers, but not the supernate recovered from incubations with suspended cells, contained carrier proteins capable of specifically binding IGF-I tracer.

IGF-I binding to detergent-solubilized fibroblast monolayers cultivated in serum-free or serum-containing media. Fibroblast monolayers maintained in serum or serum-free media were solubilized with Triton X-100, and the binding of ${ }^{125} \mathrm{I}-\mathrm{IGF}-\mathrm{I}$ to the solubilized extracts was compared. For cells grown in media containing $20 \%$ fetal calf serum, IGF-I tracer binding to the solubilized preparations was approximately seven times greater than to the intact monolayer (Table II). Tracer IGF-I binding to the solubilized preparations was inhibited by unlabeled IGF-I and by $B_{\text {IGF-I }}$ hybrid molecules, but not by insulin or A27 insulin (Fig. $8 \mathrm{~A}$ ), a specificity consistent with the predominant binding molcule being an IGF carrier protein.

After preincubation of fibroblast monolayers in binding buffer for $5 \mathrm{~h}$ at $15^{\circ} \mathrm{C}$, binding of tracer IGF-I to the monolayer increased and binding to carrier proteins released to the media decreased (Fig. 4). When monolayers that had been preincubated were solubilized with Triton X-100, approximately fourfold greater binding of IGF-I tracer to cell extracts $(23.1 \%$ of input radioactivity) than to cell monolayers ( $5.25 \%$ of input) was observed (not shown). These values compare with $31.5 \%$ of IGFI tracer bound to Triton-solubilized extracts, and $3.98 \%$ bound to monolayers of fibroblasts that had not been preincubated with buffer in the same experiment (not shown). These results suggest 


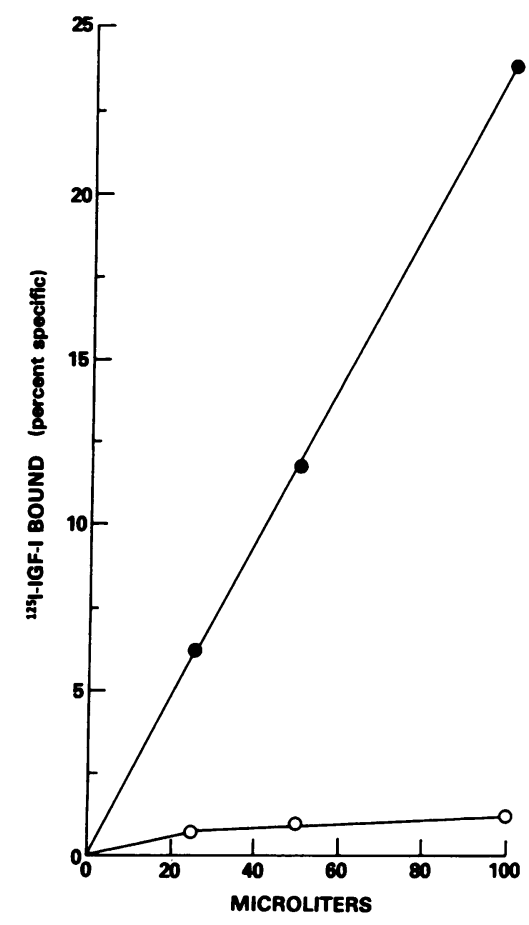

Figure 7. IGF carrier protein is released to the incubation media by fibroblast monolayers but not by suspended fibroblasts. Fibroblasts were plated in 100-mm dishes and grown to confluence in media containing 20\% fetal calf serum as described in Methods. Cells from one dish were suspended with trypsin-EDTA, washed, and incubated in HBB for $5 \mathrm{~h}$ at $15^{\circ} \mathrm{C}$ (five tubes, $0.5 \mathrm{ml} /$ tube). A second dish was washed and incubated with $2.5 \mathrm{ml}$ of $\mathrm{HBB}$ at the same time. Aliquots of supernatant media from the suspension and monolayer incubations were examined for presence of IGF carrier proteins by incubation with ${ }^{125}$ I-IGF-I, and separation of IGF-carrier protein complexes using activated charcoal as described in Methods. A blank value (i.e., radioactivity in the charcoal supernate in the absence of added carrier protein) of $6.5 \%$ of input radioactivity has been subtracted. The percent input ${ }^{125}$ I-IGF-I radioactivity specifically bound is plotted against the microliters of supernate from fibroblast monolayers $(\bullet)$ or suspended fibroblasts (O) added to the incubation. Incubation of ${ }^{125}$ I-IGF-I with $100 \mu \mathrm{l}$ of supernate from the fibroblast monolayer incubation in the presence of excess unlabeled IGF-I completely abolished the specific binding to the carrier protein (not shown).

that even though appreciable quantities of carrier protein are released from the monolayer to the media during preincubation, even greater amounts of carrier protein remain associated with the cell monolayer, possibly in internal or cryptic sites.

Quite different results were obtained when IGF-I binding was examined using Triton extracts of fibroblasts that had been maintained in serum-poor media. IGF-I tracer binding to solubilized fibroblast extracts was only $77 \%$ (range $53-113 \%$ ) of the binding observed to intact serum-poor monolayers (Table II). IGF-I binding to these solubilized extracts was inhibited by low concentrations of unlabeled IGF-I (ED S0 $\left._{50} \sim 1 \mathrm{ng} / \mathrm{ml}\right)$, inhibited $\sim 80 \%$ by $B_{1 G F-I}$ hybrid molecules at $10 \mu \mathrm{g} / \mathrm{ml}$, and $\sim 50 \%$ inhibited by insulin at $10 \mu \mathrm{g} / \mathrm{ml}$ (Fig. $8 \mathrm{~B}$ ). We interpret the fraction of binding that is inhibitable by both the hybrid molecules and insulin as binding to type I IGF receptors, whereas that fraction of the hybrid-inhibitable binding that is not inhibited by insulin is thought to represent binding to IGF carrier proteins.

It is of interest that virtually all of the tracer IGF-I binding to solubilized extracts of fibroblasts cultivated in serum or serum-
Table II. IGF-I Binding to Fibroblast Monolayers before and after Solubilization with Triton X-100

\begin{tabular}{|c|c|c|c|c|c|c|}
\hline \multirow[b]{3}{*}{ Experiment } & \multicolumn{6}{|c|}{${ }^{125}$ I-IGF-I bound ( $\%$ of input radioactivity) } \\
\hline & \multicolumn{3}{|c|}{$20 \%$ serum } & \multicolumn{3}{|l|}{$0.2 \%$ serum } \\
\hline & Cells* & Solubleł & $\begin{array}{l}\text { Soluble/ } \\
\text { cell§ }\end{array}$ & Cells* & Soluble‡ & $\begin{array}{l}\text { Soluble/ } \\
\text { cell§ }\end{array}$ \\
\hline 1 & 3.66 & 30.0 & 8.2 & 9.07 & 4.92 & 0.54 \\
\hline 2 & 6.16 & 39.9 & 6.5 & 10.84 & 9.13 & 0.84 \\
\hline 3 & 4.91 & 41.7 & 8.5 & 11.40 & 9.44 & 0.83 \\
\hline 4 & 4.62 & 34.5 & 7.5 & 10.83 & 5.76 & 0.53 \\
\hline 5 & 5.65 & 27.4 & 4.9 & 8.72 & 9.81 & 1.13 \\
\hline $\begin{array}{l}\text { Mean }(n=5) \\
( \pm S D)\end{array}$ & $\begin{array}{r}5.00 \\
( \pm 0.96)\end{array}$ & $\begin{array}{c}34.7 \\
( \pm 6.2)\end{array}$ & 6.9 & $\begin{array}{c}10.17 \\
( \pm 1.20)\end{array}$ & $\begin{array}{r}7.81 \\
( \pm 2.28)\end{array}$ & 0.77 \\
\hline
\end{tabular}

Fibroblasts were grown in 22-mm wells in Eagle's MEM containing $20 \%$ or $0.2 \%$ fetal calf serum. ${ }^{125}$ I-IGF-I binding to cell monolayers was determined. Replicate culture wells were solubilized with Triton $\mathrm{X}-100$, and ${ }^{125} \mathrm{I}-\mathrm{IGF}-\mathrm{I}$ binding to soluble proteins determined by precipitation with PEG- $\gamma$-globulin (and corrected for tracer binding to $0.1 \%$ Triton X-100 without cells). Cell numbers were $\sim 300,000$ (20\% serum) and $\sim 160,000(0.2 \%$ serum $)$, except that $\sim 250,000$ cells were present at both serum concentrations in experiment 3 .

* Percent input ${ }^{125}$ I-IGF-I bound to cell monolayers (per 22-mm well). $¥$ Percent input ${ }^{125}$ I-IGF-I bound to proteins solubilized from the 22 $\mathrm{mm}$ well by Triton $\mathrm{X}-100$.

$\S$ Ratio of radioactivity bound to Triton-solubilized extract $\div$ radioactivity bound to cell monolayer.

free media was inhibited in the presence of $B_{\text {IGF-I }}$ hybrid molecules. This suggests that binding to type II IGF receptors was not detected in the Triton-solubilized extracts, most likely because Triton failed to solubilize or inactivated the type II receptor.

Support for this interpretation comes from the observation that a different solubilization buffer (TES), containing $1 \%$ Triton $\mathrm{X}-100,5 \mathrm{mM}$ EDTA, $1 \%$ (wt/vol) sodium deoxycholate, $\pm 2 \%$ $\mathrm{N}$-octylglucoside effectively solubilized type II IGF receptors and carrier proteins, but not type I IGF receptors (results not shown). Fibroblasts cultivated in serum-free media were extracted with Triton X-100 or TES buffer. IGF-binding to the TES extracts was $\sim 140 \%$ of that to the Triton extracts. Binding to the TES extracts was not significantly inhibited by $10 \mu \mathrm{g} / \mathrm{ml}$ of insulin (indicating that type I IGF receptors were not present), and was only $50-70 \%$ inhibited by $10 \mu \mathrm{g} / \mathrm{ml}$ of $B_{\text {IGF-I }}$ hybrid (suggesting that both IGF carrier proteins and type II receptors were present).

\section{Discussion}

Type I and type II IGF receptors and IGF carrier proteins differ in their ability to bind insulin and hybrid molecules containing the A chain of insulin and the B domain of IGF-I (19). In the present study, we have used these hybrid molecules in competitive binding studies to differentiate the binding sites for IGF-I on cultured human fibroblasts studied after suspension and as monolayer cultures.

Binding of IGF-I tracer to suspended fibroblasts is inhibited by insulin and by B-IGF-I hybrids, a specificity similar to that observed for the chick embryo fibroblast type I receptor (20) and confirming that IGF-I binds predominantly to a type I IGF receptor (2, 12-14). By contrast, IGF-I binding to fibroblast monolayers is only minimally inhibited by high concentrations 


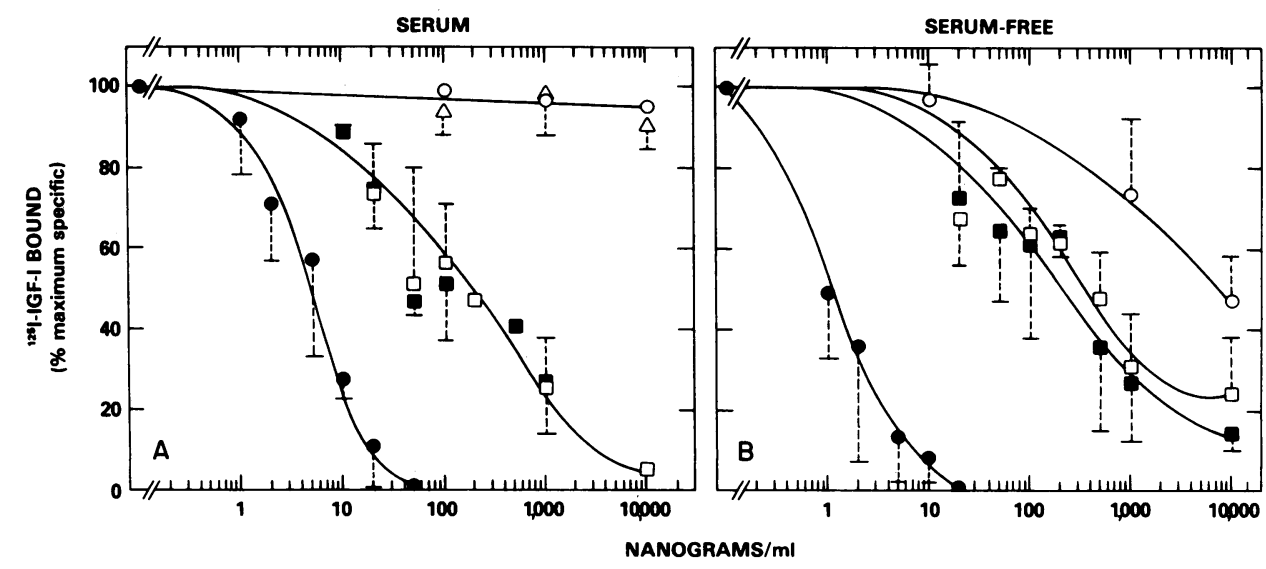

Figure 8. Inhibition of ${ }^{125}$ I-IGF-I binding to human fibroblast monolayers after solubilization with Triton X-100. Fibroblast monolayers were grown in Eagle's MEM-20\% fetal calf serum $(A)$ or cultivated in MEM- $0.2 \%$ fetal calf serum and changed to MEM containing bovine serum albumin $(B)$. The cell monolayers were solubilized with Triton X-100 as described in Methods. Solubilized proteins were incubated with ${ }^{125} \mathrm{I}$ IGF-I and the indicated concentrations of IGF-I (๑), insulin (O), $A_{\text {insulin }}-B_{\text {IGF-I }}(\square)$, A27 insulin $-B_{\text {IGF-I }}$ $(\square)$, or A27 insulin $(\Delta)$. ${ }^{125}$ I-IGF-Imacromolecule complexes were precipitated with PEG- $\gamma$-globulin. Precipitated radioactivity was corrected for ${ }^{125}$ I-IGF-I precipitated from a control incubation (i.e., tracer plus buffer containing $0.1 \%$ Triton X-100). Results are expressed as percent maximum binding. The mean \pm 1 SD of three experiments is plotted.

of insulin or B-IGF-I hybrids, suggesting predominant binding to a type II IGF receptor. This is true both for cells grown in serum-containing medium and for cells cultivated in serum-free medium. IGF-II tracer appears to bind to sites with similar specificity on fibroblast monolayers. Identification of the binding sites as type II IGF receptors will require independent confirmation by other means, inasmuch as we cannot exclude the possibility that fibroblast monolayers possess binding sites for IGF-I other than type II receptors that do not bind either insulin or the B-IGF-I hybrid molecules. ${ }^{2}$

The presence of both type I and type II IGF receptors on cultured human fibroblasts is consistent with results obtained using other experimental approaches. Type I receptors have been identified when IGF-I is cross-linked to fibroblast monolayers (14), and in Triton-solubilized extracts. Type II IGF receptors have been identifid in a membrane fraction containing both plasma and microsomal membranes (4), and in Triton-EDTAdeoxycholate-solubilized extracts of fibroblast monolayers. The type I IGF receptor appears to be a minor binding site on fibroblast monolayers, and to require either solubilization of the cells or suspension of the cells from the monolayer before they can be identified. ${ }^{3}$ Although type II IGF receptors appear to be the predominant binding site for IGF-I on fibroblast monolayers, they are not effectively cross-linked to IGF-I tracer by disuccinimidyl suberate (14). Moreover, type II receptors are not recovered in Triton extracts of the cells, and are either inactivated

3. Preliminary experiments indicate that the extensive washing associated with the cell suspension procedure rather than exposure to trypsin per se is responsible for the unmasking of the type I receptors (Wigle, G., and M. M. Rechler, unpublished results). Fibroblasts were grown to confluency in medium containing $20 \%$ fetal calf serum. Cells were suspended from half of the dishes as described in Methods. The remaining cells were treated identically except that the washed monolayer was incubated with $0.5 \mathrm{mM}$ EDTA rather than trypsin-EDTA, and the cells were detached from the culture dish by mechanical scraping. ${ }^{125}$ I-IGF-I binding to trypsin-suspended and mechanically suspended fibroblasts was inhibited by IGF-I and by insulin. Dose-response curves obtained with cells suspended by the two procedures were indistinguishable. Thus, mechanical detachment and extensive washing appear sufficient to unmask type I receptors, and to remove or inactivate virtually all of the binding to sites not inhibited by insulin. or removed by the cell suspension procedure (i.e., mild trypsin treatment and extensive washing). Thus, no single set of experimental conditions (suspension, monolayer, cross-linking, solubilization) is sufficient to allow concurrent assessment of both type I and type II receptors.

A clue to explaining the variability in IGF-I binding under different experimental conditions came from the unexpected observation of a biphasic dose-response curve for IGF-I tracer binding to monolayer cultures of fibroblasts grown in serumcontaining medium. At low concentrations of unlabeled IGF-I, IGF-tracer binding was increased to a small but significant extent. A more dramatic increase in binding was observed with higher (optimal) concentrations of B-IGF-I hybrid molecules. The increased binding does not merely reflect protection of the tracer against degradation, because no change in trichloroacetic acid precipitability of the tracer was detected after $5 \mathrm{~h}$ of incubation at $15^{\circ} \mathrm{C}$.

Because IGF-I tracer binding to fibroblast monolayers was increased to a greater extent by B-IGF-I hybrids than by IGF-I itself, and because B-IGF-I hybrids bind to IGF carrier proteins but not to type II IGF receptors, we formulated the following hypothesis: (a) IGF carrier proteins are released to the medium during the binding incubation. (b) IGF-I tracer partitions between binding sites on the cells and binding to carrier proteins in the medium. (This presumes that complexes of ${ }^{125} \mathrm{I}-\mathrm{IGF}-\mathrm{I}$ and carrier protein do not effectively bind to receptors $[5,6]$.) (c) Preferential saturation of potential IGF-I binding sites in the medium by unlabeled ligand (e.g., B-IGF-I hybrid molecules) makes more IGF-I tracer available to the cells and thereby increases binding to the cells.

The following experimental results support this model:

(a) Media harvested after incubation with fibroblast monolayers for $5 \mathrm{~h}$ at $15^{\circ} \mathrm{C}$ contained proteins that specifically bind IGF-I. When IGF-I tracer was incubated with the recovered media, complexes of tracer with media proteins could be demonstrated by gel filtration at neutral $\mathrm{pH}$ (not shown), precipitation with PEG, and after adsorption of unbound tracer with activated charcoal. Binding to these proteins was inhibited by IGF-I and by higher concentrations of B-IGF-I hybrids, but not by insulin, a specificity suggesting that the predominant protein binding IGF-I in the medium was an IGF carrier protein. 
(b) When fibroblast monolayers were incubated with ${ }^{125}$ I-IGFI, more radioactivity was associated with media proteins after 5 $h$ of incubation than with the cells. Complexes in the media at the end of the binding incubation have been demonstrated by neutral gel filtration (not shown) and by PEG precipitation.

(c) The level of unsaturated carrier protein in the incubation media correlates inversely with IGF-I tracer binding to the cell monolayer. That is, when fewer binding sites are available on carrier proteins in the media, more tracer binds to the cells. ( $i$ ) Preincubation of fibroblast monolayers in binding buffer for 5 $h$ at $15^{\circ} \mathrm{C}$ decreased the unsaturated carrier protein in the media after a second 5-h incubation, and concomitantly increased IGFI tracer binding to the cells. (ii) When fibroblast monolayers were cultivated in serum-free rather than serum-containing medium, cell-associated IGF-I tracer binding was increased whereas binding to carrier proteins in the incubation medium was decreased. (iii) Suspended fibroblasts exhibit a simple monophasic dose-response curve (i.e., no increase in tracer binding was observed at any concentration of B-IGF-I hybrid). IGF carrier proteins were not detected in media recovered after incubation with suspended fibroblasts. (iv) When cell-associated binding and IGFI tracer binding to media proteins were examined in the same competitive binding experiment, maximal tracer binding to cell receptors was observed at concentrations of unlabeled ligand that saturate the potential binding sites for IGF-I tracer in the media. This occurred at $5-10 \mathrm{ng} / \mathrm{ml} \mathrm{IGF-I} \mathrm{and} 100 \mathrm{ng} / \mathrm{ml}$ of BIGF-I hybrid, and reflects the affinity of fibroblast carrier proteins for these ligands. The greater maximum binding observed with the hybrid molecules relative to IGF-I results from the fact that at its optimal concentration it has greater selectivity for binding to carrier proteins than for cell receptors (especially type II receptors) than does IGF-I at its concentration optimum.

The preceding results demonstrate qualitatively that the concentration of unsaturated binding sites for IGF-I on IGF carrier proteins in the incubation media correlates inversely with the magnitude of IGF-I tracer binding to the fibroblast monolayers. The question remained whether the number of possible IGF-I binding sites in the media is sufficient to account quantitatively for the increase in free IGF-I tracer required to cause the observed increase in cell-associated radioactivity. For example, to account for a twofold increase in cell-associated radioactivity upon addition of optimal concentrations of B-IGFI hybrid, it would be necessary that half of the input IGF-I tracer be bound to sites in the media in the absence of the hybrid. Occupancy of the media sites by B-IGF-I hybrid would double the "free" IGF-I tracer available to bind to the cell monolayer. In the experiments presented, $<15 \%$ of the input radioactivity was precipitated from the incubation medium by $12.5 \%$ PEG. However, under these conditions only $\sim 25 \%$ of the ${ }^{125}$ I-IGF-Icarrier protein complexes in the media that are detected by neutral gel filtration are precipitated. Thus, our experimental conditions considerably underestimate the extent of IGF-I tracer binding to carrier proteins in the media. The actual number of these binding sites should be sufficient to account quantitatively for the observed increases in tracer binding to the cell monolayer.

The IGF carrier proteins released by fibroblasts during the binding incubation might represent carrier proteins synthesized by the fibroblast cultures, or residual carrier proteins sequestered from the fetal calf serum used in the initial culture media. Human fibroblasts synthesize and secrete increasing quantities of carrier protein to the media during prolonged (4-d) incubation in serum- free media (Romanus, J. A., and M. M. Rechler, unpublished results), and this release is abolished by the protein synthesis inhibitor cycloheximide (16). Moreover, protein synthesis is decreased in fibroblasts maintained in serum-free media compared to serum-containing media (Romanus, J. A., and M. M. Rechler, unpublished results). Thus, although we favor the interpretation that the carrier protein released to the media during the binding incubation with fibroblast monolayers is synthesized de novo by the fibroblasts, we cannot exclude the possibility that it represents carrier protein sequestered from the fetal calf serum. ${ }^{4}$

IGF carrier proteins appear to be present in fibroblast monolayers in both readily releasable and slowly releasable (internal) pools. Carrier proteins are readily released from the cells to the media after a 5 -h incubation at $15^{\circ} \mathrm{C}$ in binding buffer. They also are removed/inactivated by the extensive wash procedure and trypsin treatment used to suspend cells from the monolayer. ${ }^{3}$ However, considerable quantities of carrier proteins also appear to be present intracellularly, because they are liberated by extraction of fibroblast monolayers with Triton X-100 even after $5 \mathrm{~h}$ of preincubation in buffer.

Although our model requires that IGF carrier proteins be present in the media at the end of the binding incubation, further studies are required to determine when during the incubation the carrier proteins are released from the cell and when they interact with IGF-I tracer. Carrier proteins are not present in the media at the start of the incubation. They may be present on the surface of the fibroblasts, possibly masking type I IGF receptors on the intact monolayer. It is unknown whether the IGF-I tracer partitions between cell receptors and carrier proteins while the carrier proteins are on the cell surface or after they are released to the media.

Undoubtedly, the previously unsuspected role of IGF-carrier proteins in modulating IGF-I binding to fibroblasts has contributed to the variable results obtained under different experimental conditions and in different laboratories. Variations in the amount of carrier protein present in the cultures, the distribution of the carrier protein between cells and media, and the relative affinities of carrier proteins and receptors for labeled and unlabeled ligand might contribute to this variability. For example, Rosenfeld and Dollar (17) reported that somatomedin C/IGF-I tracer binding to fibroblast monolayers was inhibited in a simple dose-response curve by IGF-I, less potently by IGF-II, and $60 \%$ inhibited by high concentrations of insulin, a specificity consistent with predominant binding to a type I IGF receptor. These studies used cultures established from foreskin of a single newborn donor

4. Carrier proteins continue to be released to both incubation and culture media even after prolonged cultivation in serum-free media. Fibroblast monolayers were grown in serum-containing media, washed, and incubated in Hepes binding buffer $\left(5 \mathrm{~h}, 15^{\circ} \mathrm{C}\right)$, and the incubation media recovered (as described in Fig. $4 \mathrm{~B}$ ). The media was replaced with Eagle's MEM for $72 \mathrm{~h}$ at $37^{\circ} \mathrm{C}$, the media were collected, and a second 5-h incubation $\left(5 \mathrm{~h}, 15^{\circ} \mathrm{C}\right)$ in fresh Hepes buffer was performed. The 72-h$37^{\circ} \mathrm{C}-\mathrm{MEM}$ and $5-\mathrm{h}-15^{\circ} \mathrm{C}-\mathrm{Hepes}$ binding buffer incubations were repeated two additional times. The four sequential 5-h media collections and the three sequential $72-\mathrm{h}$ collections were assayed for carrier protein using the charcoal separation assay. The levels of carrier protein showed only a minor decrease with prolonged cultivation in serum-free media (Wigle, G., J.-F. Wang, and M. M. Rechler, unpublished results). These results suggest either that the carrier protein is continuously synthesized by fibroblast cultures in serum-free media, or that preexisting carrier protein (of unknown origin) is slowly transferred to a releasable pool. 
(instead of forearm skin of 18-20-year-old volunteers). It is unclear whether somatomedin $\mathrm{C}$ purified in their laboratory or IGF-I obtained from Humbel was used as radioligand. ${ }^{5}$ Other potential variables (growth medium, feeding schedule, cell density) do not appear to be a factor, because our most pronounced biphasic binding curves were observed in experiments performed using their conditions (Fig. $1 A$ ). Although the same authors also described somatomedin $\mathrm{C}$ binding to fibroblast monolayers established from adult forearm skin (28), they did not comment on whether insulin inhibits this binding. Thus it is not possible to determine whether this binding also was to a type I IGF receptor.

Recent results using antireceptor antibodies specific for type I IGF receptors suggest that the IGFs stimulate DNA synthesis in cultured human fibroblasts via the type I IGF receptor (29). It is curious that the type I receptors appear to be masked or in a cryptic state in fibroblast monolayers, requiring suspension of the cells before they become the predominant binding site for IGF-I. IGF carrier proteins are synthesized by cultured fibroblasts, accumulate intracellularly, and are released to the media. IGF-I binding to carrier proteins in the media and possibly on the cell surface profoundly alters IGF-I binding to IGF receptors on the fibroblast monolayer. These results suggest that carrier proteins may play an important regulatory role in IGF-I binding and action.

\section{Acknowledgment}

We thank G. T. Burke for critical reading of the manuscript, G. Wigle and J.-F. Wang for assistance, D. R. Clemmons for discussions of results prior to publication, and B. Morris for expert secretarial assistance.

Dr. Katsoyannis was supported by research grants AM-12925 and AM-29988 from the National Institute of Arthritis, Diabetes, and Digestive and Kidney Diseases.

\section{References}

1. Zapf, J., E. R. Froesch, and R. E. Humbel. 1981. The insulin-like growth factors (IGF) of human serum: chemical and biological characterization and aspects of their possible physiological role. Curr. Top. Cell Regul. 19:257-309.

2. Rechler, M. M., J. Zapf, S. P. Nissley, E. R. Froesch, A. C. Moses, J. M. Podskalny, E. E. Schilling, and R. E. Humbel. 1980. Interaction of insulin-like growth factors I and II and multiplication stimulating activity with receptors and serum carrier proteins. Endocrinology. 107: 1451-1459.

3. Kasuga, M., E. Van Obberghen, S. P. Nissley, and M. M. Rechler. 1981. Demonstration of two subtypes of insulin-like growth factor receptors by affinity crosslinking. J. Biol. Chem. 256:5305-5308.

4. Massague, J., and M. P. Czech. 1982. The subunit structures of two distinct receptors for insulin-like growth factors I and II and their relationship to the insulin receptor. J. Biol. Chem. 257:5038-5045.

5. Rechler, M. M., and S. P. Nissley. 1985. Receptors for insulinlike growth factors. In Receptors for Polypeptide Hormones. B. I. Posner, editor. Marcel Dekker, New York. 227-297.

6. Rechler, M. M., and S. P. Nissley. 1985. The nature and regulation of the receptors for insulin-like growth factors. Annu. Rev. Physiol. 47: 427-445.

5. Somatomedin C purified in Van Wyk's laboratory is identical to IGF-I in amino acid sequence (18). Chemical characterization of the somatomedin C preparation purified and used by Rosenfeld and Dollar (17) has not been reported.
7. King, G. L., C. R. Kahn, M. M. Rechler, and S. P. Nissley. 1980. Direct demonstration of separate receptors for growth and metabolic activities of insulin and multiplication-stimulating activity (an insulinlike growth factor) using antibodies to the insulin receptors. J. Clin. Invest. 66:130-140.

8. Kasuga, M., E. Van Obberghen, S. P. Nissley, and M. M. Rechler. 1982. Structure of the insulin-like growth factor receptor in chicken embryo fibroblasts. Proc. Natl. Acad. Sci. USA. 79:1864-1868.

9. Mottola, C., and M. P. Czech. 1984. The type II insulin-like growth factor receptor does not mediate increased DNA synthesis in $\mathrm{H}-35$ hepatoma cells. J. Biol. Chem. 259:12705-12713.

10. Rechler, M. M., J. M. Podskalny, I. D. Goldfine, and C. A. Wells. 1974. DNA synthesis in human fibroblasts: stimulation by insulin and by nonsuppressible insulin-like activity (NSILA-s). J. Clin. Endocrinol. Metab. 39:512-520.

11. Knight, A. B., M. M. Rechler, J. A. Romanus, E. E. Van Obberghen-Schilling, and S. P. Nissley. 1981. Stimulation of glucose incorporation and amino acid transport by insulin and insulin-like growth factor in fibroblasts with defective insulin receptors cultured from a patient with leprechaunism. Proc. Natl. Acad. Sci. USA. 78:2554-2558.

12. Rechler, M. M., S. P. Nissley, J. M. Podskalny, A. C. Moses, and L. Fryklund. 1977. Identification of a receptor for somatomedin-like polypeptides in human fibroblasts. J. Clin. Endocrinol. Metab. 44:820 831.

13. Van Obberghen-Schilling, E. E., M. M. Rechler, J. A. Romanus, A. B. Knight, S. P. Nissley, and R. E. Humbel. 1981. Receptors for insulin-like growth factor I are defective in fibroblasts cultured from a patient with leprechaunism. J. Clin. Invest. 68:1356-1365.

14. Rechler, M. M. 1982. Leprechaunism and related syndromes with primary insulin resistance: heterogeneity of molecular defects. In Membranes and Genetic Disease. J. R. Sheppard, V. E. Anderson, and J. W. Eaton, editors. Alan R. Liss, Inc. New York. 245-281.

15. Clemmons, D. R., L. E. Underwood, and J. J. Van Wyk. 1981 Hormonal control of immunoreactive somatomedin production by cultured human fibroblasts. J. Clin. Invest. 67:10-19.

16. Adams, S. O., M. Kapadia, B. Mills, and W. H. Daughaday. 1984. Release of insulin-like growth factors and binding protein activity into serum-free medium of cultured human fibroblasts. Endocrinology. 115:520-526.

17. Rosenfeld, R. G., and L. A. Dollar. 1982. Characterization of the somatomedin-C/insulin-like growth factor I (SM-C/IGF-I) receptor on cultured human fibroblast monolayers: regulation of receptor concentrations by SM-C/IGF-I and insulin. J. Clin. Endocrinol. Metab. 55: 434-440.

18. Klapper, D. G., M. E. Svoboda, and J. J. Van Wyk. 1983. Sequence analysis of somatomedin-C: Confirmation of identity with insulinlike growth factor I. Endocrinology. 112:2215-2217.

19. De Vroede, M. A., M. M. Rechler, S. P. Nissley, S. Joshi, G. T. Burke, and P. G. Katsoyannis. 1985. Hybrid molecules containing the B-domain of insulin-like growth factor I (IGF-I) are recognized by IGF carrier proteins. Proc. Natl. Acad. Sci. USA. 82:3010-3014.

20. De Vroede, M. A., M. M. Rechler, S. P. Nissley, H. Ogawa, S. Joshi, G. T. Burke, and P. G. Katsoyannis. 1985. Mitogenic activity and receptor activity of hybrid molecules containing portions of the insulinlike growth factor-I (IGF-I), IGF-II, and insulin molecules. Diabetes. In press.

21. Ogawa, H., G. T. Burke, and P. G. Katsoyannis. 1984. Synthesis and biological evaluation of a modified insulin incorporating the $\mathrm{C}$-terminal hexapeptide ("D-Region") of insulin-like growth factor II. J. Protein Chem. 3:327-348.

22. Joshi, S., G. T. Burke, and P. G. Katsoyannis. 1985. Synthesis of an insulin-like compound consisting of the A-chain of insulin and a B-chain corresponding to the B-domain of human insulin-like growth factor I. Biochemistry. 24:4208-4214.

23. Greenstein, L. A., S. P. Nissley, A. C. Moses, P. A. Short, Y. W.-H. Yang, L. Lee, and M. M. Rechler. 1984. Purification of multiplication-stimulating activity. In Methods for Preparation of Media, 
Supplements, and Substrata for Serum-Free Animal Cell Culture. D. W. Barnes, D. A. Sirbasku, and G. A. Sato, editors. Alan R. Liss, Inc., New York. 111-138.

24. Hintz, R. L., and F. Liu. 1979. Human somatomedin plasma binding proteins. In Somatomedin and Growth. G. Giordano, J. J. Van Wyk, and F. Minuto, editors. Academic Press, Ltd., London. 143-147.

25. Moses, A. C., S. P. Nissley, J. Passamani, R. M. White, and M. M. Rechler. 1979. Further characterization of growth hormone dependent somatomedin-binding proteins in rat serum and demonstration of somatomedin-binding proteins produced by rat liver cells in culture. Endocrinology. 104:536-546.

26. Cuatrecasas, P. 1972. Isolation of the insulin receptor of liver and fat-cell membrane. Proc. Natl. Acad. Sci. USA. 69:318-322.
27. Yang, Y. W.-H., J. A. Romanus, T-Y. Liu, S. P. Nissley, and M. M. Rechler. 1985. Biosynthesis of rat insulin like growth factor II (rIGF-II). I. Immunochemical demonstration of a $\sim 20,000$ dalton biosynthetic precursor of rat IGF-II in metabolically labeled BRL-3A rat liver cells. J. Biol. Chem. 260:2570-2577.

28. Rosenfeld, R. G., L. A. Dollar, and C. A. Conover. 1984. Densityassociated loss of functional receptors for somatomedin-C/insulinlike growth factor I (SM-C/IGF-I) on cultured human fibroblast monolayers. J. Cell. Physiol. 121:419-424.

29. Van Wyk, J. J., D. C. Graves, S. J. Casella, and S. Jacobs. 1985. Evidence from monoclonal antibody studies that insulin stimulates deoxyribonucleic acid synthesis through the type I somatomedin receptor. J. Clin. Endocrinol. Metab. 61:639-643. 